\title{
Alaska Daylight Time
}

National Cancer Institute

\section{Source}

National Cancer Institute. Alaska Daylight Time. NCI Thesaurus. Code C116261.

Local daylight-savings time, based at the 135th meridian west of the Greenwich

Observatory, established as eight hours behind Coordinated Universal T ime. 